\title{
Preparation, Electronic Properties, and Powder-XRD Structure Analysis of 3,5- Bis(pyridin-2-yl)-H-1,2,4-triazoledichloridocopper(II)
}

\author{
Kristian Handoyo Sugiyarto ${ }^{1, *}$, Isti Yunita ${ }^{1}$, and Harold Andrew Goodwin ${ }^{2}$ \\ ${ }^{1}$ Department of Chemistry Education, Universitas Negeri Yogyakarta, Jl. Colombo No. 1, Yogyakarta 55281, Indonesia \\ ${ }^{2}$ School of Chemistry, UNSW, Sydney, NSW 2052, Australia
}

*Corresponding author:

tel: $+62-8157935534$

email: sugiyarto@uny.ac.id

Received: April 22, 2020

Accepted: May 30, 2020

DOI: $10.22146 /$ ijc. 55600

\begin{abstract}
Salt of [Cu(bptrzH)Cl $\left.l_{2}\right],($ bptrzH $=3,5$-bis(pyridin-2-yl)-H-1,2,4-triazole) has been prepared and characterized its electronic spectral and magnetic properties. This salt is paramagnetic with magnetic moment, $\mu_{s}$, being 1.77-1.78 BM at $293 \mathrm{~K}$, but decreased significantly with decreasing temperature to be 0.60-0.63 BM at $90 \mathrm{~K}$, indicating antiferromagnetic nature. This is associated with $\mathrm{Cu}-\mathrm{Cu}$ magnetic interactions at low temperatures, and suggests that the salt adopt an octahedrally polymeric structure. The electronic spectrum of this salt reveals a strong ligand field band centered at about $13,000 \mathrm{~cm}^{-1}$ and a very strong charge transfer absorption at about 23,000-24,000 $\mathrm{cm}^{-1}$. The spectrum is better resolved at lower temperature and this is parallel to the slight change in color from yellowish-green at room temperature to bright green at low temperature $(90 \mathrm{~K})$. The powder XRD of this complex was refined by Le Bail method of Rietica program and found to be fit as triclinic symmetry of space group PI with the figure of merit: $R_{p}=5.02 ; R_{w p}=7.95 ; R_{\exp }=5.40 ;$ Bragg $R$-Factor $=0.05$; and $G O F=2.166$.
\end{abstract}

Keywords: magnetic moment; copper(II); bptrzH; antiferromagnetic; spectrum; Rietica

\section{INTRODUCTION}

The coordination chemistry of $\mathrm{Cu}(\mathrm{II})$ is of interest for many researchers, particularly due to the various 4-6 coordination numbers, its magnetism associated with ferro-/antiferro-magnetic property, the ability to form bipoly nuclear compound, and strong Jahn-Teller distortion. In four coordination as in $\left[\left(\mathrm{C}_{2} \mathrm{H}_{5}\right)_{2} \mathrm{NH}_{2}\right]_{2}\left[\mathrm{CuCl}_{4}\right]$, the tetrachloridocuprate(II) was reported an interesting thermochromism from bright green at room- to lowtemperatures to yellow on heating above $43^{\circ} \mathrm{C}[1-2]$. This is associated with the geometrical phase transition, square-planar (green) $\rightleftharpoons$ tetrahedral (yellow) in anionic tetrachloridocuprate(II). The phase transition is confirmed primarily due to organic counter-part change arrangement [3]. The driving force for this geometric transition is believed because of the cationic counterpart movements of particular organic species [2], while the thermochromic nature according to Bhattacharya et al., is evident due to the Jahn-Teller effects of $\mathrm{Cu}(\mathrm{II})$ and $\mathrm{NH}$.... Cl hydrogen bonds [4]. Since then, other studies also reported the thermochromic properties in other copper(II) compounds. Fabbrizzi et al. [5] observed continuous and discontinuous thermochromism of copper(II). The role of the organic counterpart cation to the tetrachloridocuprate(II) is then confirmed in other numerous compounds [6-11].

Another characteristic of copper(II) species is its ability to form numerous di-/poly-nuclear compounds which usually lead to typical magnetic interaction effect, that is ferro-/anti-ferromagnetic properties [12-15]. The $\mathrm{d}^{9}$ system of $\mathrm{Cu}(\mathrm{II})$ is also well known to show structurally Jahn-Teller distortion as it has been observed in octahedral, trigonal bipyramidal, square-planar, and tetrahedral geometries, accompanying the phase transition and thus the importance in functional molecular and inorganic materials is of interest [16]. It should also be noted that the $\mathrm{Cu}$ (II) complexes discussed might involve bridging system $\mathrm{Cu}(\mathrm{II})$-ligand-Cu(II) as well as interligand hydrogen bonds which might be considered to account of magnetic interactions. The organic compound, 3,5-bis(pyridine-2-yl)-1,2,4-triazole, 


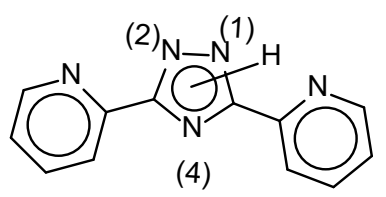

(bptrzH)

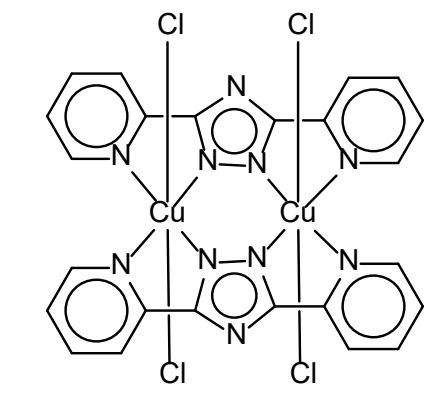

(b) (a)
Fig 1. Possible asymmetrically flanking bptrzH (a) and dinuclear double bridging framework with $\mathrm{CuCl}_{2}$ (b)

bptrzH (Fig. 1(a)) has been known as a ligand that can provide bridging-coordination to transition metal compounds due to conformation of the ligand [17]. Thus bptrz $\mathrm{H}$ might coordinate through $\mathrm{N}^{2}$ and $\mathrm{N}^{4}$ donor atoms leading to dinuclear single bridging $\left(\mathrm{N}^{2}, \mathrm{~N}_{\mathrm{py}}, \mathrm{N}^{4}, \mathrm{~N}_{\mathrm{py}}{ }^{\prime}\right)$ complex. It might also be possible to coordinate through $\mathrm{N}^{1}$ and $\mathrm{N}^{2}$ donor atoms leading to dinuclear double bridging $\left(\mathrm{N}_{\mathrm{py}}, \quad \mathrm{N}^{1}-\mathrm{N}^{2}, \mathrm{~N}_{\mathrm{py}}{ }^{\prime}\right)_{2}$ when both pyridine rings are symmetrically flanking to the triazole ring (Fig. 1(b)). However, mononuclear meridional tris-bidentate, $\mathrm{N}_{\mathrm{py}}$, $\mathrm{N}^{2}$, is also possible to occure [18-19].

Therefore, preparation of a complex containing this organic ligand with copper(II) chloride which has not been studied, is very promising characteristics at least associated with ferro and antiferro magnetic properties for the bridging complex. Moreover, the chloride ion may also act as a bridging anionic ligand. Hence, the combination of the two species, bptrzH and chloride ion is expected to produce $\mathrm{Cu}(\mathrm{II})$ complex with interesting properties.

\section{- EXPERIMENTAL SECTION}

\section{Materials}

The main chemicals of picolinic acid hydrazide, 2cyanopyridine, methanol, and $\mathrm{CuCl}_{2} \cdot 2 \mathrm{H}_{2} \mathrm{O}$, were purchased from Sigma-Aldrich. All the reagents were used without initial purification.

\section{Procedure for Preparation of the Complex}

\section{Preparation of ligand}

The compound (bptrzH) was synthesized according to method of Kubota et al. [20]. A mixture of picolinic acid hydrazide, $6.857 \mathrm{~g}(0.05 \mathrm{~mol})$, and 2-cyanopyridine, $52.055 \mathrm{~g}(0.5 \mathrm{~mol}$, in excess), were heated together at 220 $225{ }^{\circ} \mathrm{C}$ for about $10 \mathrm{~h}$. After cooling, the solid was filtered, washed with cold ethanol, and dried in a vacuum desiccator. Recrystallization from ethanol resulted in white solid (mp. $196^{\circ} \mathrm{C}$ uncorrected, lit. 209$\left.211^{\circ} \mathrm{C}\right)$.

\section{Preparation of complex [Cu(bptrzH) $\mathrm{Cl}_{2}$ ]}

Into a well stirred methanolic solution of $\mathrm{CuCl}_{2} \cdot 2 \mathrm{H}_{2} \mathrm{O}, 0.341 \mathrm{~g}(2 \mathrm{mmol})$, was added dropwise of a methanolic solution of bptrzH, $0.233 \mathrm{~g}(1 \mathrm{mmol})$, whereupon the finely greenish-yellow powders came out readily. It was carefully filtered, washed with cold methanol, and then dried in aeration. (Sample 1 and 2 were separately prepared).

\section{Instruments and Procedure of Physical Measurements}

\section{Physical characterization}

Magnetic measurements. The magnetic data for solid samples were obtained using a Newport variable temperature Gouy balance equipped with cryostat containing liquid nitrogen for low-temperature measurements and calibrated with $\mathrm{CoHg}(\mathrm{NCS})_{4}$. All data have been corrected for diamagnetism calculated using Pascal's constants. Molar susceptibilities $\left(\chi_{M}\right)$ were quoted in $\mathrm{cm}^{3} \mathrm{~mol}^{-1}$ and the magnetic moments were calculated according to the relationship $\mu_{\mathrm{ef}}=2.828$ $\sqrt{ }\left(\chi_{M} \cdot T\right) B M$.

Electronic spectral measurements. Electronic spectra were recorded on a Zeiss PMQII spectrophotometer equipped with a diffuse reflectance accessory. Solid (powder) samples were spread on white filter paper and their spectra were calibrated against magnesium oxide. For low-temperature measurement a special brass attachment with silica glass windows was used. The fitting was sealed and a stream of cold nitrogen gas was passed over the assembly to prevent condensation. The fitting was then placed in contact with the base of an insulated brass dewar filled with liquid nitrogen and low-temperature measurement was made. In the measurement of spectra of the sample at room- and low-temperatures, the sample mounting was 
not changed and hence any measured changes in intensities at different temperatures are significant even though the actual values for intensities are not.

Powder X-ray diffraction. The diffractogram of the complex was recorded by using a Rigaku Miniflex 600 $40 \mathrm{~kW} 15 \mathrm{~mA}$ Benchtop Diffractometer, with $\mathrm{CuK}_{\alpha}, \lambda=$ $1.5406 \AA$. The powdered sample was spread on the glass plate and then was placed on the cell holder. The reflection data were recorded in a scan mode at 2-80 (degree of $2 \theta$ ) with interval of 0.04 steps per $4 \mathrm{sec}$ for $2 \mathrm{~h}$. The recorded diffractogram was then analyzed with the Rietica program of Le Bail method (5-80 degree of 20) which was run within 30 cycles.

\section{- RESULTS AND DISCUSSION}

\section{Elemental Analysis of bptrzH and the Complex}

BptrzH was isolated as white solid having melting point $\left(196{ }^{\circ} \mathrm{C}\right)$ close to the literature $\left(209-211^{\circ} \mathrm{C}\right)$. The elemental analysis was found to be $\mathrm{C}=64.79(64.56), \mathrm{H}=$ 3.84 (4.06), and $\mathrm{N}=31.05$ (31.37)\%, with calculated figures in the bracket for $\mathrm{C}_{12} \mathrm{H}_{9} \mathrm{~N}_{5} .{ }^{1} \mathrm{H}-\mathrm{NMR}$ spectrum of this compound confirms the corresponding formula, showing four strong resonances at 7.3,7.8, 8.4, and $8.8 \mathrm{ppm}$ by integration ratio of 1:1:0.9:1 respectively. Thus, this corresponds to the four different positions of hydrogen atoms in pyridine rings. The weak and broad resonance at $13.6 \mathrm{ppm}$ is believed to be due to the only one $\mathrm{H}(\mathrm{N})$ in the triazole ring [20].

Direct interaction of copper(II) chloride with bptrzH $\left(\mathrm{C}_{12} \mathrm{H}_{9} \mathrm{~N}_{5}\right)$ in methanol resulted in greenish-yellow finely powder. The $\mathrm{C}-\mathrm{H}-\mathrm{N}$ elemental analysis, $\mathrm{C}=38.90$ (39.19), $\mathrm{H}=1.97$ (2.46), $\mathrm{N}=18.71$ (19.28)\%, with calculated figures in the bracket for $\left[\mathrm{Cu}\left(\mathrm{C}_{12} \mathrm{H}_{9} \mathrm{~N}_{5}\right) \mathrm{Cl}_{2}\right]$, signify this complex formula.

\section{Magnetic Moment}

The effective magnetic moment for the complex at room temperature, $\mu_{293 \mathrm{~K}}$, is $1.77-1.78 \mathrm{BM}$. This is remarkably close to the spin-only value for one unpaired electron $\left(\mu_{\mathrm{s}}=1.73 \mathrm{BM}\right)$ in $\mathrm{d}^{9}$-octahedral configuration. The effective magnetic moment, however, is significantly temperature dependent, being gradually decreased with decreasing temperature to about $0.61-0.63 \mathrm{BM}$ at $89-99 \mathrm{~K}$, and increased with increasing temperature to about $1.85-1.92 \mathrm{BM}$ at $353-373 \mathrm{~K}$. The change in moment was found to be reversible as shown by the magnetic data listed in Table 1 which were recorded according to the order of measurements. The trend of decrease in the moment as displayed in Fig. 2 suggests the possibility of further decreases at very low temperatures.

The decreasing magnetic moment within the experimental temperatures in this compound is associated with the antiferromagnetic behavior due to the interaction of metal atoms, $\mathrm{Cu}-\mathrm{Cu}$. No effect of externally magnetic field is observed as shown by the moment values recorded with $15 \mathrm{~A}$ at $176-90 \mathrm{~K}$ (sample 1) and at $156-89 \mathrm{~K}$ (sample 2 ). As temperature is gradually lowered the $\mathrm{Cu}(\mathrm{II})-\mathrm{Cu}(\mathrm{II})$ distance in the molecule becomes gradually shorter, and the interaction of the one unpaired electron in $\mathrm{Cu}(\mathrm{II})-\mathrm{Cu}(\mathrm{II})$ becomes stronger. The magnetic interaction should be then an anti-parallel couple spin of electron, and as a result the magnetic moment is lowered. The reproducibility of this behavior in this complex is confirmed by magnetic data from the two samples (sample 1-2) which were separately prepared in different batch. This antiferromagnetic behavior is much the same as the plot of magnetic susceptibility with temperature in another octahedral dimer, $\left[\mathrm{Cu}(\text { bptrzH })\left(\mathrm{CF}_{3} \mathrm{SO}_{3}\right) \mathrm{H}_{2} \mathrm{O}\right]_{2}$ [18]. Such typical behavior

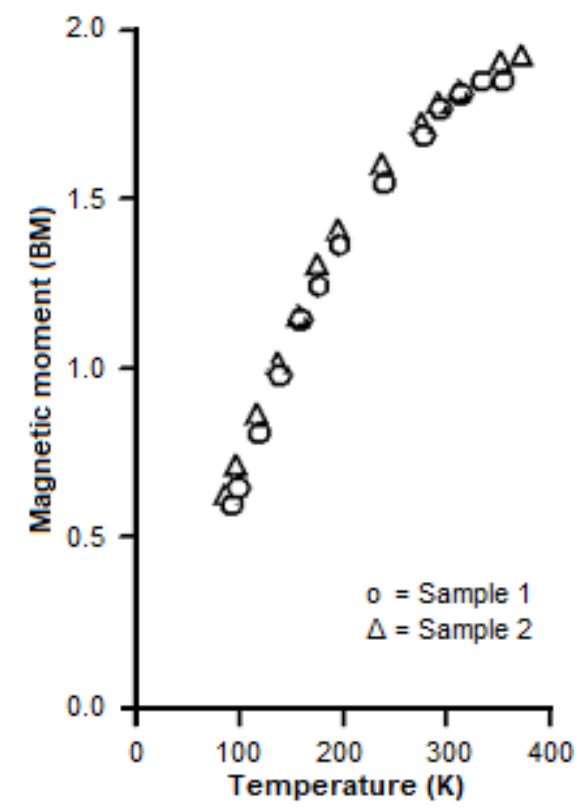

Fig 2. Magnetic moment of $\left[\mathrm{Cu}(b p t r z H) \mathrm{Cl}_{2}\right]$ 
Table 1. Magnetic moment of $\left[\mathrm{Cu}(b p t r z H) \mathrm{Cl}_{2}\right]$ at various temperatures

\begin{tabular}{lccccc}
\hline \multicolumn{1}{c}{ Sample 1} & \multicolumn{3}{c}{ Sample 2} \\
\hline $\mathrm{T} / \mathrm{K}$ & $\chi_{\mathrm{M}} / 10^{-6}$ & $\mu_{\mathrm{ef}} / \mathrm{BM}$ & $\mathrm{T} / \mathrm{K}$ & $\chi_{\mathrm{M}} / 10^{-6}$ & $\chi_{\mathrm{M}} / \mathrm{BM}$ \\
\hline 293.2 & 1336 & 1.77 & 293.2 & 1359 & 1.78 \\
176.3 & 1115 & 1.25 & 237.2 & 1346 & 1.60 \\
$176.3(\mathbf{1 5 A})^{*}$ & 1175 & 1.28 & 156.5 & 1072 & 1.16 \\
90 & 500 & 0.60 & $156.5(\mathbf{1 5 A})^{*}$ & 1081 & 1.16 \\
$90(\mathbf{1 5 A})^{*}$ & 518 & 0.61 & 89 & 551 & 0.63 \\
99 & 531 & 0.65 & $89(\mathbf{1 5 A})^{*}$ & 550 & 0.63 \\
118.1 & 689 & 0.81 & 99 & 632 & 0.71 \\
137.2 & 878 & 0.98 & 118.1 & 785 & 0.86 \\
156.5 & 1052 & 1.15 & 137.2 & 952 & 1.02 \\
195.8 & 1194 & 1.37 & 176.3 & 1219 & 1.31 \\
237.2 & 1273 & 1.55 & 195.8 & 1272 & 1.41 \\
275 & 1304 & 1.69 & 275 & 1352 & 1.72 \\
313.2 & 1304 & 1.81 & 313.2 & 1326 & 1.82 \\
333.2 & 1288 & 1.85 & 353.2 & 1286 & 1.90 \\
353.2 & 1209 & 1.85 & 373.2 & 1245 & 1.92 \\
\hline
\end{tabular}

* The moment was measured in different (electro)magnetic fields, by applying electric current $15 \mathrm{~A}$ vs $10 \mathrm{~A}$, and it turned out to give relatively the same results, indicating that the magnetic properties do not depend on external magnetic field strength

in magnetism is very common for poly- or di-nuclear copper(II) with ligand other than $b p t r z H$ due to $\mathrm{Cu}-\mathrm{Cu}$ interaction and the role of counterion [12-14,21], ferromagnetic-antiferromagnetic coupling [15-16] and ferromagnetic domain [22]. Thus, this complex is proposed to be dimer $\left[\mathrm{Cu}(\text { btrzH }) \mathrm{Cl}_{2}\right]_{2}$ (as in Fig. 1(b)) following Prins et al. [18].

\section{Electronic Spectrum}

The electronic spectrum of this complex, $\left[\mathrm{Cu}(\right.$ bptrzH $\left.) \mathrm{Cl}_{2}\right]$, as shown in Fig. 3, reveals two well resolved of absorption bands. The peak at lower energy which is relatively asymmetrical band centered at around $13,000 \mathrm{~cm}^{-1}$ should be the octahedral ligand-field band attributed as ${ }^{2} E_{\mathrm{g}} \rightarrow{ }^{2} T_{2 \mathrm{~g}}$ while the one centered at much higher energy, around 23,000-24,000 $\mathrm{cm}^{-1}$ might be associated with the "charge-transfer" band of metalligand, $\pi-\pi^{*}$, and this is what dominates the greenish yellow color of this species. A very clear shoulder band at around $16000 \mathrm{~cm}^{-1}$ might be associated with Jahn-Teller distortion [16,23-24] due to primarily asymmetrical electronic configuration in $\mathrm{e}_{\mathrm{g}}{ }^{3}$ orbitals.

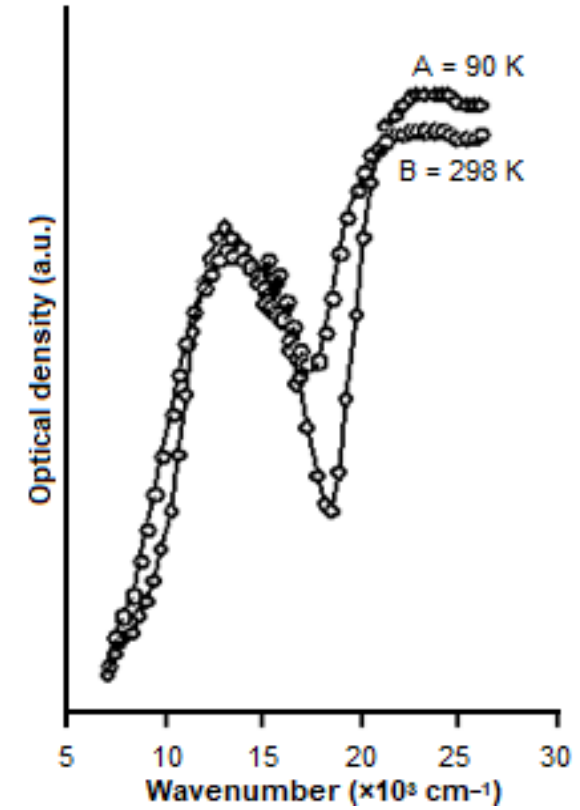

Fig 3. Electronic spectra of $\left[\mathrm{Cu}(b p t r z H) \mathrm{Cl}_{2}\right]$

\section{Structural Analysis}

The complex compound resulted from interaction of copper(II) chloride and bptrzH apparently does not dissolve in a various commonly known solvents, water, 


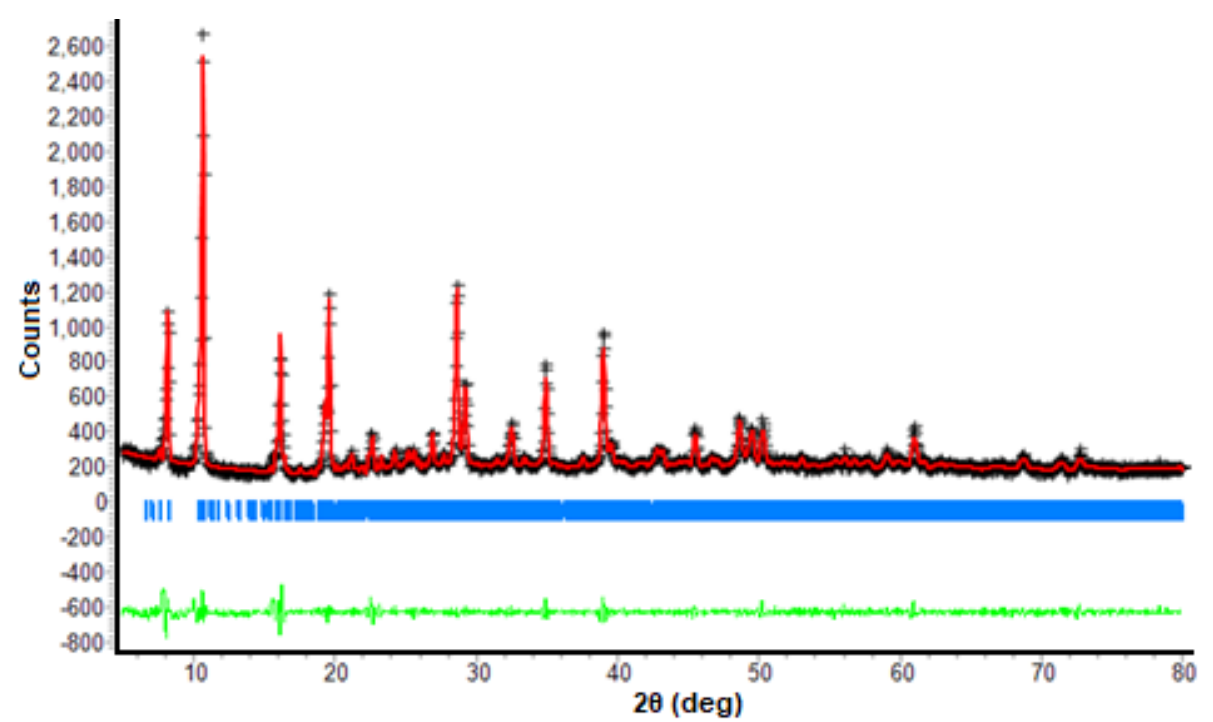

Fig 4. Diffractogram of $\left[\mathrm{Cu}(\right.$ bptrzH $\left.) \mathrm{Cl}_{2}\right]$. The black signs (+) represent the observed-experimental data, the red full line is the calculated refinement at $5-80^{\circ}$ of $2 \theta$ for the expected model of triclinic symmetry of space group PI which are the blue bar-lines, and the green curve-line indicates the differences between the observed diffractogram and the refinement

nitromethane, ethanol, methanol, acetone, acetonitrile, and so far attempt to grow a single crystal was unsuccessful. Structural analysis was then performed from its powder XRD. This is quite common for the oxides compounds following Rietveld method [e.g. 2527]. However, it has been applied to that of iron(II) complex [28] quite recently and found to be a significant result. Since then, referring to the suggestion by Toby as well [29], application of this method has been extensively performed to some powdered complexes [30-38] and the results were found to be reasonably acceptable.

For these reasons, the powder X-ray diffraction of this complex was then recorded and the diffractogram together with its refinement following Le Bail method of Rietica program is shown in Fig. 4. It is obvious that the calculated red full line does almost pass through the black experimentally observed data, and this is confirmed by the almost linear green-curve line which reflects the tiny difference between both data. This suggests that the refinement is considerably fit for triclinic symmetry of space group PI with Goodness of Fitting (GOF) 2.166, derived Bragg R-Factor 0.05, and low figures of merit: $R_{p}$ $=5.02, R_{w p}=7.95$, and $R_{\exp }=5.40$. The detailed cell

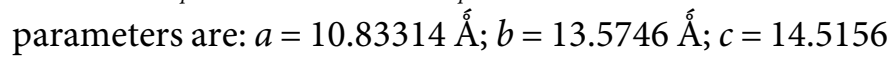

Table 2. Detailed cell parameters of (a), $\left[\mathrm{Cu}(\text { bptrzH })_{2} \mathrm{Cl}_{2}\right]$, and (b)

\begin{tabular}{|c|c|c|}
\hline Compound & (a) & (b) $[18]$ \\
\hline Symmetry & Triclinic & Triclinic \\
\hline Space Group & PI & Pİ \\
\hline$a(\AA)$ & 10.8331 & $8.841(3)$ \\
\hline$b(\AA ̊)$ & 13.5746 & $14.132(6)$ \\
\hline$c(\AA)$ & 14.5156 & $14.382(6)$ \\
\hline$V\left(\AA^{3}\right)$ & 1965.1938 & $1606(1)$ \\
\hline$\alpha\left(^{\circ}\right)$ & 112.3884 & $112.58(3)$ \\
\hline$\beta\left(^{\circ}\right)$ & 86.0523 & $92.23(3)$ \\
\hline$\gamma\left({ }^{\circ}\right)$ & 94.8069 & $102.45(3)$ \\
\hline$R_{p}$ & 5.02 & \\
\hline$R_{w p}$ & 7.95 & \\
\hline$R_{\exp }$ & 5.40 & \\
\hline Z & 2 & 2 (dimer) \\
\hline GOF: $\chi^{2}$ & 2.166 & \\
\hline$R_{\text {Bragg }}$ & 0.05 & \\
\hline
\end{tabular}

(b) $\left[\mathrm{Cu}(b p t r z H)\left(\mathrm{CF}_{3} \mathrm{SO}_{3}\right)\left(\mathrm{H}_{2} \mathrm{O}\right)\right]_{2}$

Á; $\alpha=112.3884^{\circ} ; \beta=86.0523^{\circ} ; \gamma=94.8069^{\circ} ; \mathrm{V}=$ $1965.1938 \AA^{3}$; and $Z=2$ (Table 2).

The antiferromagnetic interaction of $\mathrm{Cu}(\mathrm{II})$ at lower temperatures suggests that this complex is likely to adopt a dimer of $\left[\mathrm{Cu}(\text { bptrzH }) \mathrm{Cl}_{2}\right]_{2}$ (Fig. 1(b)) following the structure of $\left[\mathrm{Cu}(b p t r z H)\left(\mathrm{CF}_{3} \mathrm{SO}_{3}\right)\left(\mathrm{H}_{2} \mathrm{O}\right)\right]_{2}$ [18] 
which is known as dinuclear double bridging as also observed in spin crossover system of $\left[\mathrm{Fe}_{2}(b p t r z)_{2} \mathrm{Cl}_{4}\right]$ [19].

\section{- CONCLUSION}

The complex of $\left[\mathrm{Cu} \quad(b p t r z H) \mathrm{Cl}_{2}\right]$ has been successfully isolated as greenish-yellow finely powder from the reaction of copper(II) chloride with the bptrzH ligand which is insoluble in some common solvents. The complex shows antiferromagnetic $\mathrm{Cu}-\mathrm{Cu}$ interactions with magnetic moment of $1.78 \mathrm{BM}$ at $293 \mathrm{~K}$ and gradually down with temperatures to $0.63 \mathrm{BM}$ at $90 \mathrm{~K}$. It is believed to have a geometrical structure of dinuclear double bridging octahedral coordination.

\section{- ACKNOWLEDGMENTS}

Thanks to the Department of Inorganic Chemistry, the School of Chemistry, UNSW - Australia, which provided this research facility

\section{- REFERENCES}

[1] Willett, R.D., Haugen, J.A., Lebsack, J., and Morrey, J., 1974, Thermochromism in copper(II) chlorides. Coordination geometry changes in $\mathrm{CuCl}_{4}{ }^{2-}$ anions, Inorg. Chem., 13 (10), 2510-2513.

[2] Willett, R.D., Ferraro, J.R., and Choca, M., 1974, Pressure studies on the thermochromic salt $\left[\left(\mathrm{CH}_{3}\right)_{2} \mathrm{CHNH}_{3}\right]_{2} \mathrm{CuCl}_{4}$, a compound with three phases containing distinctly different $\mathrm{CuCl}_{4}{ }^{2-}$ stereochemical configurations, Inorg. Chem., 13 (12), 2919-2921.

[3] Ding, J., Li, H.S., Wen, L.W., Kang, X.B., Li, H.D., and Zhang, J.M., 2013, Electronic and magnetic properties of an organic multiferroic: $\left(\mathrm{C}_{2} \mathrm{H}_{5} \mathrm{NH}_{3}\right)_{2} \mathrm{CuCl}_{4}$, J. Magn. Magn. Mater., 346, 91-95.

[4] Bhattacharya, R., Ray, M.S., Dey, R., Righi, L., Bocelli, G., and Ghosh, A., 2002, Synthesis, crystal structure and thermochromism of benzimidazolium tetrachlorocuprate: $\left(\mathrm{C}_{7} \mathrm{H}_{7} \mathrm{~N}_{2}\right)_{2}\left[\mathrm{CuCl}_{4}\right]$, Polyhedron, 21 (25-26), 2561-2565.

[5] Fabbrizzi, L., Micheloni, M., and Paoletti, P., 1974, Continuous and discontinuous thermochromism of copper(II) and nickel(II) complexes with N,N-diethyl ethylenediamine, Inorg. Chem., 13 (12), 3019-3021.
[6] Hamdi, M., Oueslati, A., Chaabane, I., and Hlel, F., 2012, Characterization and electrical properties of $\left[\mathrm{C}_{6} \mathrm{H}_{9} \mathrm{~N}_{2}\right]_{2} \mathrm{CuCl}_{4}$ compound, ISRN Condens. Matter Phys., 2012, 750497.

[7] Lee, C.H., Lee, K.W., and Lee, C.E., 2003, Quasitwo-dimensional magnetism in $\left(\mathrm{C}_{n} \mathrm{H}_{2 n+1} \mathrm{NH}_{3}\right)_{2} \mathrm{CuCl}_{4}$ studied by electron paramagnetic resonance, Curr. Appl. Phys., 3 (6), 477-479.

[8] Zolfaghari, P., de Wijs, G.A., and de Groot, R.A., 2013, The electronic structure of organic-inorganic hybrid compounds: $\left(\mathrm{NH}_{4}\right)_{2} \mathrm{CuCl}_{4},\left(\mathrm{CH}_{3} \mathrm{NH}_{3}\right)_{2} \mathrm{CuCl}_{4}$ and $\left(\mathrm{C}_{2} \mathrm{H}_{5} \mathrm{NH}_{3}\right)_{2} \mathrm{CuCl}_{4}$, J. Phys. Condens. Matter, 25 (29), 295502.

[9] Aldrich, E.P., Bussey, K.A., Connell, J.R., Reinhart, E.F., Oshin, K.D., Mercado, B.Q., and Oliver, A.G., 2016, Crystal structure of the thermochromic bis(diethylammonium) tetrachloridocuprate(II) complex, Acta Cryst. E, 72 (1), 40-43.

[10] Vishwakarma, A.K., Kumari, R., Ghalsasi, P.S., and Arulsamy, N., 2017, Crystal structure, thermochromic and magnetic properties of organicinorganic hybrid compound: $\left(\mathrm{C}_{7} \mathrm{H}_{7} \mathrm{~N}_{2} \mathrm{~S}\right)_{2} \mathrm{CuCl}_{4}, J$. Mol. Struct., 1141, 93-98.

[11] Kapustyanyk, V.B., and Korchak, Y.M., 2000, Thermochromic phase transition in $\left[\mathrm{NH}_{2}\left(\mathrm{C}_{2} \mathrm{H}_{5}\right)_{2}\right]_{2}$ $\mathrm{CuCl}_{4}$ crystals, J. Appl. Spectrosc., 67 (6), 1045-1049.

[12] Zhang, L., Bu, W.M., Yan, S.P., Jiang, Z.H., Liao, D.Z., and Wang, G.L., 2000, Weaker magnetic interactions of oxalato-copper(II) binuclear compounds: Synthesis, spectroscopy, crystal structure and magnetism, Polyhedron, 19 (9), 11051110.

[13] Julve, M., Gleizes, A., Chamoreau, L.M., Ruiz, E., and Verdaguer, M., 2017, Antiferromagnetic interactions in copper(II) $\mu$-oxalato dinuclear complexes: The role of the counterion, Eur. J. Inorg. Chem., 2018 (3-4), 509-516.

[14] Gusev, A.N., Nemec, I., Herchel, R., Shul'gin, V.F., Ryush, I., Kiskin, M., Efimov, N., Ugolkova, E., Minin, V., Lyssenko, K., Eremenko, I., and Linert, W., 2019, Copper(II) self-assembled clusters of bis( (pyridin-2-yl)-1,2,4-triazol-3-yl)alkanes. Unusual 
rearrangement of ligand upon reaction condition, Dalton Trans., 48 (9), 3052-3060.

[15] Chaudhuri, P., Wagner, R., and Weyhermüller, T., 2007, Ferromagnetic vs antiferromagnetic coupling in bis( $\mu$-phenoxo)dicopper(II) complexes. Tuning of the nature of exchange coupling by remote ligand substituents, Inorg. Chem., 46 (13), 5134-5136.

[16] Halcrow, M.A., 2013, Jahn-Teller distortions in transition metal compounds, and their importance in functional molecular and inorganic materials, Chem. Soc. Rev., 42 (4), 1784-1795.

[17] Chen, J.C., Hu, S., Zhou, A.J., Tong, M.L., and Tong, Y.X., 2006, Synthesis, crystal structures, and magnetic properties of three new iron complexes derived from 3,5-bis(pyridin-2-yl)-1,2,4-triazole, Z. Anorg. Allg. Chem., 632 (3), 475-481.

[18] Prins, R., Birker, P.J.M.W.L., Haasnoot, J.G., Verschoor, G.C., and Reedijk, J., 1985, Magnetic properties of dimeric disubstituted-triazole copper(II) compounds. X-ray structure of bis[ $\mu$-3,5-bis(pyridin2-yl)-1,2,4-triazolato- $\left.N^{p}, N^{1}, N^{2}, N^{\prime \prime}\right]$-bis[aqua(trifluoro methanesulfonato-O)copper(II)], Inorg. Chem., 24 (24), 4128-4133.

[19] Kitchen, J.A., and Brooker, S., 2008, Spin crossover in iron(II) complexes of 3,5-di(2-pyridyl)-1,2,4triazoles and 3,5-di(2-pyridyl)-1,2,4-triazolates, Coord. Chem. Rev., 252 (18-20), 2072-2092.

[20] Kubota, S., Uda, M., and Nakagawa, T., 1975, 1,2,4Triazoles. V. Nuclear magnetic resonance study of $N$ methyl derivatives of 1,2,4-triazoles, J. Heterocycl. Chem., 12 (5), 855-860.

[21] Zhou, J.H., Cheng, R.M., Song, Y., Li, Y.Z., Yu, Z., Chen, X.T., Xue, Z.L., and You, X.Z., 2005, Syntheses, structures, and magnetic properties of unusual nonlinear polynuclear copper(II) complexes containing derivatives of 1,2,4-triazole and pivalate ligands, Inorg. Chem., 44 (22), 8011-8022.

[22] Aqeel, A., Akhtar, N., Polyakov, A.O., Rudolf, P., and Palstra, T.T.M., 2018, Magnetic functionality of thin film perovskite hybrids, APL Mater., 6 (11), 114206.

[23] Conradie, J., Conradie, M.M., Tawfiq, K.M., Coles, S.J., Tizzard, G.J., Wilson, C., and Potgieter, J.H., 2018, Jahn-Teller distortion in 2-pyridyl-(1,2,3)- triazole-containing copper(II) compounds, New J. Chem., 42 (19), 16335-16345.

[24] Scăețeanu, G.V., Chifiriuc, M.C., Bleotu, C., Kamerzan, C., Măruţescu, L., Daniliuc, C.G., Maxim, C., Calu, L., Olar, R., and Badea, M., 2018, Synthesis, structural characterization, antimicrobial activity, and in vitro biocompatibility of new unsaturated carboxylate complexes with 2,2'bipyridine, Molecules, 23 (1), 157.

[25] Aughterson, R.D., Lumpkin, G.R., de los Reyes, M., Sharma, N., Ling, C.D., Gault B., Smith, K.L., Avdeev, M., and Cairney, J.M., 2014, Crystal structures of orthorhombic, hexagonal, and cubic compounds of the $\mathrm{Sm}\left({ }_{\mathrm{x}}\right) \mathrm{Yb}(2-\mathrm{x}) \mathrm{TiO}_{5}$ series, J. Solid State Chem., 213, 182-192.

[26] Lüdtke, T., Weber, D., Schmidt, A., Müller, A., Reimann, C., Becker, N., Bredow, T., Dronskowski, R., Ressler, T., and Lerch, M., 2017, Synthesis and characterization of metastable transition metal oxides and oxide nitrides, Z. Kristallogr. Cryst. Mater., 232 (1-3), 3-14.

[27] Purwaningsih, S.Y., Rosidah, N., Zainuri, M., Triwikantoro, T., Pratapa, S., and Darminto, D., 2019, Comparation of X-ray diffraction pattern refinement using Rietica and MAUD of $\mathrm{ZnO}$ nanoparticles and nanorods, J. Phys. Conf. Ser., 1153, 012070.

[28] Grosjean, A., Négrier, P., Bordet, P., Etrillard, C., Mondieig, D., Pechev, S., Lebraud, E., Létard, J.F., and Guionneau, P., 2012, Crystal structures and spin crossover in the polymeric material $\left[\mathrm{Fe}(\mathrm{Htrz})_{2}(\mathrm{trz})\right]\left(\mathrm{BF}_{4}\right)$ including coherent-domain size reduction effects, Eur. J. Inorg. Chem., 2013 (56), 796-802.

[29] Toby, B.H., 2006, R factors in Rietveld analysis: How good is good enough?, Powder Diffr., 21 (1), 67-70.

[30] Sugiyarto, K.H., Saputra, H.W., Permanasari, L., and Kusumawardani, C., 2017, Structural analysis of powder complex of $\left[\mathrm{Mn}(\text { phen })_{3}\right]\left(\mathrm{CF}_{3} \mathrm{SO}_{3}\right)_{2} \cdot 6.5 \mathrm{H}_{2} \mathrm{O}$, AIP Conf. Proc., 1847, 040006.

[31] Kusumawardani, C., Permanasari, L., Fatonah S.D., and Sugiyarto, K.H., 2017, Structural analysis of 
powder complex of tris(1,10-phenanthroline) copper(II) trifluoromethane sulfonate dihydrate, Orient. J. Chem., 33 (6), 2841-2847.

[32] Kusumawardani, C., Kainastiti, F., and Sugiyarto, K.H., 2018, Structural analysis of powder complex of $\left[\mathrm{Cu}(\text { bipy })_{3}\right]\left(\mathrm{CF}_{3} \mathrm{SO}_{3}\right)_{2}\left(\mathrm{H}_{2} \mathrm{O}\right)_{\mathrm{x}}(\mathrm{x}=0.5,1)$, Chiang Mai J. Sci., 45 (4),1944-1952.

[33] Sutrisno, H., Kusumawardani, C., Rananggana, R.Y., and Sugiyarto, K.H., 2018, Structural analysis of powder tris(phenanthroline)nickel(II) trifluoro acetate, Chiang Mai J. Sci., 45 (7), 2768-2778.

[34] Sugiyarto, K.H., Kusumawardani, C., Sutrisno, H., and Wibowo, M.W.A., 2018, Structural analysis of powdered manganese(II) of 1,10-phenanthroline (phen) as ligand and trifluoroacetate (TFA) as counter anion, Orient. J. Chem., 34 (2), 735-742.
[35] Sugiyarto, K.H., Kusumawardani, C., and Wulandari, K.E., 2018, Synthesis and structural analysis of powder complex of tris(bipyridine) cobalt(II) trifluoromethanesulfonate octahydrate, Indones. J. Chem., 18 (4), 696-701.

[36] Sugiyarto, K.H., Kusumawardani, C., Wigati, H., and Sutrisno, H., 2019, Structural study of the powder complex of $\mathrm{Cu}(\mathrm{II})-1,10$-phenanthrolinetrifluoroacetate, Orient. J. Chem., 35 (1), 325-331.

[37] Louise, I.S.Y., Nabila, S., and Sugiyarto, K.H., 2019, Complex of tris(phenanthroline)cobalt(II) trifluoro acetate: Characterisation and powder XRD analysis, Orient. J. Chem., 35 (5), 1500-1507.

[38] Sugiyarto, K.H., Louise, I.S.Y., and Wilujeng, S.S., 2020, Preparation and powder XRD analysis of tris (2,2'-bipyridine)nickel(II) trifluoroacetate, Indones. J. Chem., 20 (4), 833-841. 